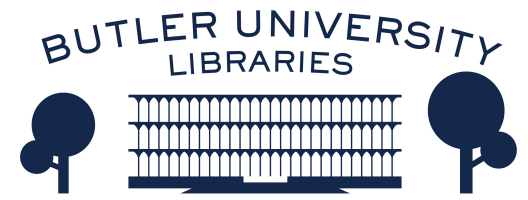

Journal of Hindu-Christian Studies

\title{
Book Review: "The White Woman's Other Burden: Western Women and South Asia during British Rule"
}

Margot Wilson-Moore

Follow this and additional works at: https://digitalcommons.butler.edu/jhcs

Part of the Religion Commons

\section{Recommended Citation}

Wilson-Moore, Margot (1998) "Book Review: "The White Woman's Other Burden: Western Women and South Asia during British Rule"," Journal of Hindu-Christian Studies: Vol. 11, Article 18.

Available at: https://doi.org/10.7825/2164-6279.1191

The Journal of Hindu-Christian Studies is a publication of the Society for Hindu-Christian Studies. The digital version is made available by Digital Commons @ Butler University. For questions about the Journal or the Society, please contact cbauman@butler.edu. For more information about Digital Commons @ Butler University, please contact digitalscholarship@butler.edu. 
generous use of the quotations from the speeches given at the event. By reading their actual words we are caught up into the idealism and grandiosity and ethnocentrism of their thought and culture. We see for ourselves that the Parliament failed "because the God of the organizers ... turned out not to be quite the same as the God of the Asians". (p.xxix) In Part One, the context is described in which the Parliament took place - the World Columbian Exposition. Part Two presents the encounter between Eastern and Western religions as it unfolded on the Parliament floor. Part Three examines the responses of the press and representative figures to the events as they unfolded. A fine historian of religion, Seager makes these events come alive in the mind of the reader. Seager takes us back to the glory days of the 1890s when Americans eagerly awaited the coming of the 20th-century global society in which the European JudeoChristian tradition would reign supreme. But he also shows the Parliament pulling Americans up short, making them aware of other religions and opening the door to Eastern missionaries to America (e.g. Vivekananda's Ramakrishna Mission).

Seager concludes that the 1893 World's Parliament was a watershed event, signalling the beginning of the end of Protestant triumphalism in America and offering the start of a new religious pluralism that now, one hundred years later, is just reaching full flower. The Parliament also encouraged its Hindu, Buddhist, and Jaina spokesmen to return home and establish revitalization and modernization movements in their home cultures and religions (e.g. Dharmapala's revival of Buddhism in Ceylon and India).

This book is clearly the classic work on the 1893 Parliament of Religions - one you will want to keep on your bookshelf.

Harold Coward

University of Victoria

\section{"The White Woman's Other Burden": Western Women and South Asia during British Rule. Kumari Jayawardena. New York: Routledge, 1995, x + $310 \mathrm{pp}$.}

THE FIRST THING I had to do was to purchase a new three-way bulb for my lamp so that I was able to read the very fine, closely-typed pages. This, however, is probably the worst criticism I have of this interesting volume. It is a daunting task that the author sets for herself. Beginning from a Universalist perspective on women's subordination, Jayawardena presents a detailed depiction of the roles and activities of foreign women in the context of colonial India with relatively few biases and an impressive attention to detail. In her introduction Jayawardena (p. 4-5) clearly delineates her subject matter:

These were the famous "Women of the Raj": who have been written about extensively and are depicted in literature, films and television serials as brave, long-suffering and strong, or as racist, stupid, and neurotic. What has not emerged, however, was the reality of the colonial wife, living in a sort of doubly refined bondage-isolated in the home as woman and alienated in the colony as a foreigner. This book does not deal with them.

It does deal, however, with other categories of women who had different perceptions of the East. [these] white women had their origins in the reality of the "new woman" who was asserting herself on all fronts. Women all over the world had made one of the most remarkable "leaps" in history in the late 
19th and early 20th centuries. Spurred on by the principles of the French revolution and the Declaration of the Rights of Man, women took up the challenge and proclaimed "the Rights of Women.

Accordingly, Jayawardena ushers in a panorama of woman missionaries, social activists, theosophists, Orientalists, teachers, feminists, devotees, and Holy Mothers, both well-known and little known, whose experiences paint an alternative history of colonial India. $\mathrm{Oh}$, the great men are there, but only as husbands, colleagues, and gurus of these women. Jayawardena (p. 18) begins by defining two archetypes of foreign women: “'devils' - reviled, condemned, jailed and deported" and "'goddesses' worshipped, honoured and celebrated". The dichotomy based on comments made by an Indian judge following the publication of Mother India in 1927, presents Sister Nivedita (a disciple of Vivekananda) and Katherine Mayo (the author of Mother India) as polarized representatives of these two categories. Mayo, on the one hand, characterized the ignoble/bad aspect of foreign women in India: intolerant, arrogant, proselytizing, and culturally conformist, attacking local customs and religion from a eurocentric bias. Nivedita, by contrast, characterized the noble/good foreign women who found South Asian culture not only interesting and attractive, but perhaps more acceptable than their own, who sympathized with and supported South Asian values and who either as individuals, or with their husbands, partners, and gurus, actively fought against colonial oppression and entered into the politics of national liberation. Divided into five sections, the volume considers, in the first section, the work of Christian missionaries, whose intent lay in Christianizing and modernizing Asian societies through education and conversion. Social reformers, sometimes called secular missionaries, including female physicians and radical feminists whose concerns for
South Asia women lay outside the traditional purview of Christianity, who were concerned instead with such issues as women's health, child marriage, and suti are the focus of the second section. In the third section, theosophists and Orientalists are presented as women who rejected Christianity as the only true religion and sought alternatives in "Eastern" ideals and spirituality. "White women in search of black gods" are the subject of the fourth section. These are women who chose to make India their home, often permanently, who attached themselves to sages and political leaders. These include Margaret Noble (Nivedita), Madeleine Slade (Gandhi's companion and helpmate, Mira Behn), and Mirra Aurobindo (the "Mother" of Pondicherry). The final section discusses the contributions of women socialists who participated in left-wing revolutionary politics in India and Sri Lanka. These include Evelyn Roy, Agnes Smedley, and Doreen Wickremasinghe. In the final chapter, Jayawardena characterizes these women and their experiences as "varied and multi-faceted" and not fitting neatly into the dichotomous categories of "devils". or "goddesses". Instead, she argues, one must view their lives in the historical context of colonial India and as they were embedded in broader religious, social, liberal, revolutionary, and feminist processes at work in the world outside South Asia. She presents the biases and shortcomings of these women as openly as she presents their successes. Education, argues Jayawardena, is the one common issue which unites all of these women, viewed by them as the key factor in the emancipation of South Asian women. In conclusion, Jayawardena (p. 267) characterizes the motivation of foreign women in colonial South Asia, quoting Kamaladevi Chattopadhyaya (1986) writing of Agnes Smedley: "She strode forward into some of the stormiest earth shaking events of international history. She braved wars and shattering turmoil because of her 
single-minded devotion to the downtrodden, and the oppressed." Thus, Jayawardena (p. 267-8) claims a kind of "sisterhood" for these women, united in their confrontation of and resistance to patriarchy, their firm stand against imperialism, and their willingness to speak out against the exploitation and oppression of women and other social ills in South Asia. By bringing a feminist perspective to bear on a heavily researched period in history, this carefully researched, well-written volume provides an interesting and readable alternative to more traditional histories of India. Beyond this, by casting an "Asian feminist gaze" on the lives of the women discussed, Jayawardena highlights their contribution to the liberation of women generally and, in some cases, to national liberation as well. She brings into question both the British Liberal view and the standard nationalist interpretation of South Asian history and the roles of foreign women in it. In doing so, she protects the legacy of these women which might otherwise have been "erased from memory and history in both Asian and the West" (p. x).

Margot Wilson-Moore

University of Victoria

\section{The Beginning and End of Religion. Nicholas Lash. Cambridge: Cambridge University Press, 1996. 284 pp.}

READERS OF THIS journal will find the first three chapters of Lash's book of particular interest as they contain the text of his 1994 Teape Lectures, reflecting upon, as the endowment requires, "The Upanishads in the Catholic Church". The lectures were delivered in India. The remaining eleven chapters deal with theology and science (4$6)$, theology and secular modernity (7-10), and Christian hope (11-14). While some of the chapters in the second section of the book are immensely important and all of them are stimulating and entertaining, I shall focus on only the first three chapters, given the specialist focus of this journal. If the book can be said to contain a single overall argument it would have to be that one welcome effect of the collapse of modernity is to challenge the view of "religion" constructed by modernity: i.e. that it is a private concern which should keep out of the public sphere.

Lash is like a poet. One begins to see things differently after reading him, and describing an argument or thesis within his work is an appropriately problematic endeavour. It is a masterly stroke to invite someone who has no (self-confessed) expertise on Hinduism, but who is a gifted Christian theologian to reflect on ChristianHindu themes. One shortcoming is perhaps inevitable: a lack of scholarly depth regarding the Hindu tradition. But this is made up eloquently by Lash's unrestrained delight in dealing with new materials and his modest restraint regarding any far-reaching claims or conclusions.

The first chapter brings to bear a resolutely historical sensibility upon the question of "religion". Lash's thesis which is well substantiated, is that "religions" were essentially a seventeenth-century invention falsely predicated upon a model of different species of a common genus. This construction was part of the enlightenment project (see also ch. 7 for a more detailed discussion of the genesis of this project) which inevitably, in the nineteenth century, slotted the Eastern religions into an already distorted matrix. Lash's remedy is to view religious traditions as pedagogic schools for cultivating practices and virtues which may or may not relate to similar outcomes. (Despite this tradition-specific outlook, he 